\title{
Salt tectonics in front of the Outer Carpathian thrust wedge in the Wieliczka area (S Poland) and its exposure in the underground salt mine
}

\author{
Stanisław Burliga ${ }^{1}$, Piotr Krzywiec ${ }^{2}$, Krzysztof Dąbroś ${ }^{3}$, Jerzy Przybyło \\ Elżbieta Włodarczyk ${ }^{3}$, Michał Źróbek ${ }^{3}$, Michał Słotwiński ${ }^{1}$ \\ ${ }^{1}$ University of Wrocław, Institute of Geological Sciences; pl. M. Borna 9, 50-204 Wrocław, Poland; \\ e-mail: stanislaw.burliga@uwr.edu.pl \\ ${ }^{2}$ Polish Academy of Science, Institute of Geological Sciences; ul. Twarda 51/55, 00-818 Warsaw, Poland \\ ${ }^{3}$ Kopalnia Soli “Wieliczka” S.A.; Park Kingi 1, 32-020 Wieliczka, Poland \\ (C) 2018 Authors. This is an open access publication, which can be used, distributed and reproduced in any medium according \\ to the Creative Commons CC-BY 4.0 License requiring that the original work has been properly cited.
}

Received: 5 February 2018; accepted: 28 February 2018

\begin{abstract}
Salt deposits in the Wieliczka area (Wieliczka Salt Deposit - WSD) in southern Poland comprise saltrich strata belonging to an evaporite succession that originated in the Carpathian Foredeep basin in the Middle Miocene Badenian (Serravallian) times, ca 13.81-13.45 Ma. Although they have been mined since the $13^{\text {th }}$ century and decades of investigations provided abundant data on their origin and structure, some aspects of their geological evolution are still not fully understood. This study presents current concepts on the lithostratigraphy and tectonics of the WSD.

The salt-bearing facies developed near to the southern basin margin, delineated by the Carpathian orogenic front. Such a location triggered the redeposition of sediments and gravity-driven deformation followed by tectonic deformation related to the forelandward advancement of the Carpathian thrusts. As a result, the WSD consists of folds and slices composed of two main salt members: (1) the stratified salt member, with intercalating salt, sulphates and siliciclastics, and (2) the boulder salt member, built of clays with large, isolated blocks of salt. The stratified member contains abundant meso-scale tectonic structures recording the soft-sediment deformation and deformation related to the northward tectonic push exerted by the advancing Carpathian thrust wedge. The boulder member originated due to the syntectonic erosion of evaporites along the basin margins and their redeposition during progressive northward migration of the Carpathian front. Recent interpretations of seismic data imply that the WSD constitutes the core of a triangle zone developed at the contact of the Carpathian orogenic wedge with the backthrust-displaced foredeep sedimentary fill. Meso-scale examples of sedimentary and tectonic structures in the salt-bearing succession exposed in the underground Wieliczka Salt Mine are described and their formation modes discussed.
\end{abstract}

Keywords: Carpathian Foredeep, Miocene, salt tectonics, Wieliczka Salt Deposit

\section{INTRODUCTION}

The structural style of deformation of sedimentary rock complexes depends primarily on their tectonic setting and lithological variation. The key role in the deformation is played by weak rock layers such as rock salt and shale. These lithological types promote the development of décollements, detachments, thrusts and folds due to their specific rheological and physical properties (relatively low density and viscosity, and high water content), which significantly differ from those related to other sedimentary rock types. Thrust-and-fold belts affected by actively involved rock salt and 
shale packages are known both from contractional provinces, such as orogenic belts (e.g. Davis \& Engelder 1985, Sans \& Vergés 1995, Callot et al. 2012, Bahroudi \& Koyi 2014, Carillo et al. 2017), and from continental margin environments which originated in response to extension (Weimer \& Buffler 1992, Cobbold et al. 1995, Morley \& Guerin 1996, Rowan et al. 2004, Cartwright et al. 2012, Rowan et al. 2012). In the latter case, the gravity-triggered deformation of sediments is dual in style: extensional structures develop over steeper segments of the slope and contractional thrust-and-fold belts form over areas of diminishing slope angle. There are also provinces where orogenic belts override adjacent foreland sedimentary basins, in which the extensional basin-stage tectonic structures are superposed by orogenic belt-derived contractional ones. Such cases have been studied e.g. in Himalayan, Zagros, Pyrenean and Carpathian foreland basins (Vergés et al. 1985, Lillie et al. 1987, Puigdefàbregas et al. 1992, Oszczypko 1998, Oszczypko et al. 2006, Bahroudi \& Koyi 2014, Carillo et al. 2017). It has long been known that salt bearing rock complexes may be piled up at the front of orogenic belts, however, it is only during the last few decades that it has been realized that they can constitute the cores of triangle zones which developed on a regional scale along the frontal contacts of orogenic wedges with the sedimentary fill of their foredeeps (cf. e.g. Krzywiec \& Vergés 2007 and references therein).

The majority of tectonic structures occurring in such geological settings are recognized only as large-scale events, based on seismic sections and/or borehole and surface data interpretations. Relatively little information has been published to date on the detailed structural style of salt-rich complexes deformed either on sedimentary basin slopes or in thrust-fold belts. This mostly results from the lack of appropriate exposures. In fact, the only locations where such a deformation can be studied are underground salt mines. A unique opportunity to study in detail many aspects of the structure and tectonics of salt-bearing strata deformed in a foreland basin overridden by an orogenic wedge is afforded by the ancient Wieliczka Salt Mine located at the very thrust front of the Carpathian orogenic belt (Fig. 1).

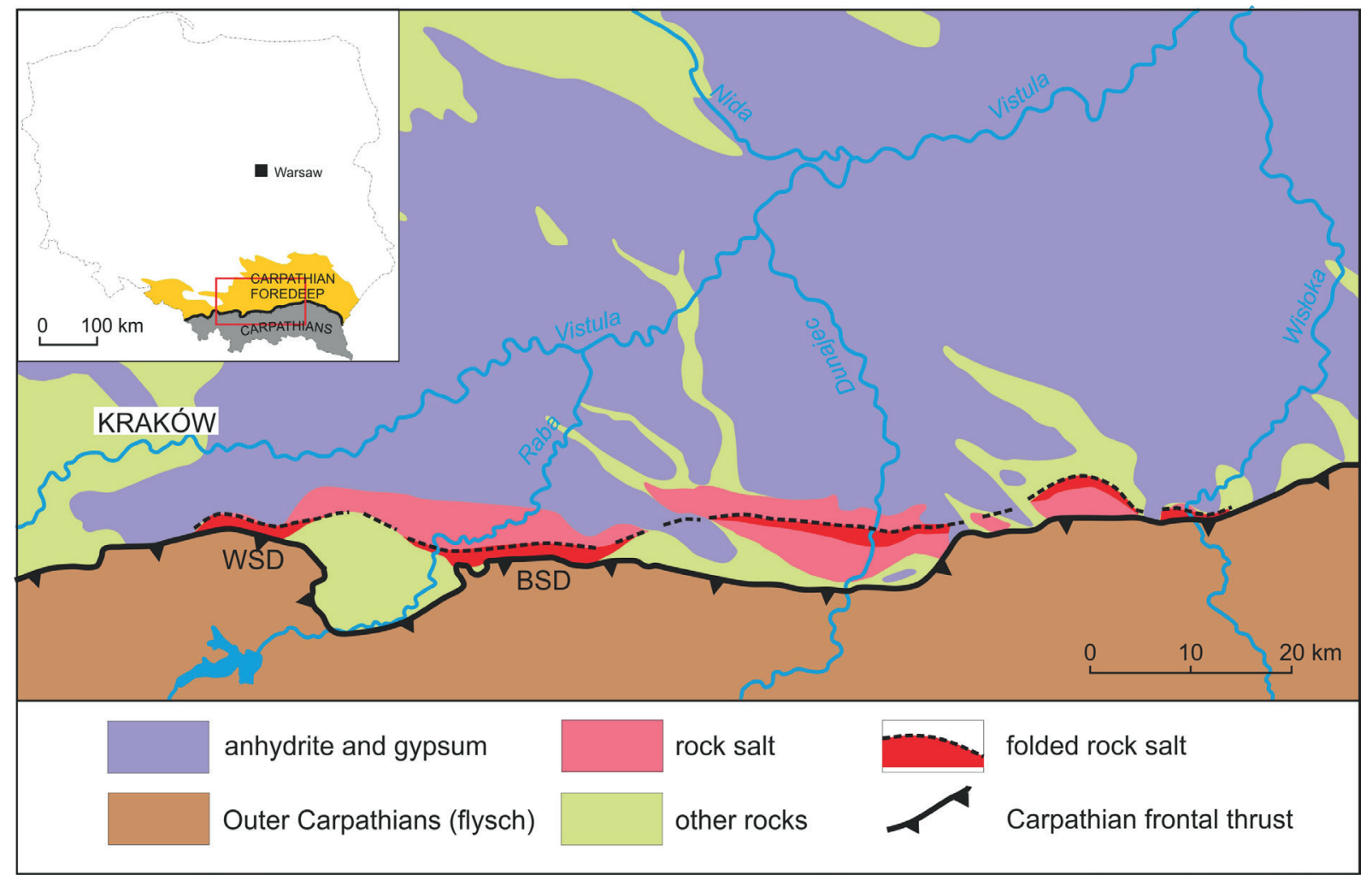

Fig. 1. Salt deposits in the Polish Carpathian Foredeep and location of the study area. WSD - Wieliczka Salt Deposit; BSD Bochnia Salt Deposit. Distribution of evaporites after Bukowski (2011) 
This paper introduces the reader to the geological setting and overall tectonics of the Wieliczka Salt Deposit (WSD) - a belt of salt-rich rocks trending along the Carpathian edge in the vicinity of the town of Wieliczka. It gives an overview of the current state of knowledge about the origin, structure and evolution of this Miocene salt-bearing evaporite succession. Subsequently, it offers a more detailed description of exemplary phenomena illustrating the geology and tectonics of the WSD on a meso-scale, exposed in the underground galleries and chambers of the Wieliczka Salt Mine.

\section{A BRIEF HISTORY OF SALT MINING AND GEOLOGICAL RECOGNITION OF THE WSD}

Salt deposits in the Wieliczka area in southern Poland were excavated from at least the $13^{\text {th }}$ century, when the first documented shaft was constructed, and this had been preceded by the production of evaporated salt, dating back to Neolithic times, 3300-2500 BC (Jodłowski, 1988, d'Obyrn \& Przybyło 2010). The early development of salt mining in the area was facilitated by the local structural conditions, where Miocene salt-bearing strata had been tectonically squeezed out from below the advancing thrust sheet wedge, displaced and piled up at shallow subsurface along the Carpathian orogenic front. The oldest preserved maps by M. German (1645, fide d'Obyrn \& Przybyło 2010) documenting the salt works in Wieliczka show that there were already three mining levels at Wieliczka in the $17^{\text {th }}$ century. In the 1730-ies, the first cross-section across the WSD was published by Borlach (fide d'Obyrn \& Przybyło 2010). Relatively modern structural research and exploration of the salt deposits began in the $19^{\text {th }}$ century. At that time, the first realistic geological cross-sections were published and the occurrence of thrusting phenomena was documented (Hrdina 1842, Zejszner 1844). A comprehensive description of the surface and subsurface geology showing the evaporite succession was published by Niedźwiedzki (1883-1884). Over the next hundred years of mining, dozens of shafts and more than $300 \mathrm{~km}$ of drifts and chambers were mined over nine levels. In 1996, salt extraction ended and since then the mining works have focused on the protection of this unique industrial and cultural monument, inscribed on UNESCO's World Heritage List in 1978. Although it became a famous tourist attraction as early as at the end of the $17^{\text {th }}$ century, its potential as a unique geological attraction is still underappreciated.

\section{REGIONAL SETTING}

The WSD occurs within an elongated belt of Miocene salt-bearing evaporite succession, deposited in the Carpathian Foredeep (Fig. 1). This was a foreland basin developing in front of the Carpathian orogeny, which, at present, stretches over a distance of $\sim 1300 \mathrm{~km}$, from Vienna in Austria, through Czechia, Poland and Ukraine, to Romania (e.g. Oszczypko et al. 2006, Wysocka et al. 2016). The Polish segment of the Carpathian Foredeep (PCF) is ca $300 \mathrm{~km}$ long and, outside the Carpathians, varies in width from a few kilometers near to Kraków, up to $90 \mathrm{~km}$ further east. The basin formed part of the Parathethys and was being filled with mostly clastic sediments in the Early and Middle Miocene, the evaporites documenting only an episode of chemical sedimentation in the Middle Miocene (Badenian).

The PCF was overridden from the south, by up to $50 \mathrm{~km}$, by the advancing Outer Carpathian thrust wedge, which resulted in the partial incorporation of the PCF's synorogenic Miocene fill in the thrust system (e.g. Oszczypko 1997, 1998, Krzywiec et al. 2004, 2014, Oszczypko et al. 2006, Głuszyński \& Aleksandrowski 2016). This led to the subdivision of the PCF into two subunits: the inner PCF, which is situated beneath the Carpathian nappes, and the outer PCF, extending north of the Carpathians' margin (Oszczypko 1997, 1998, Oszczypko et al. 2006).

Along the northern margin of the Outer Carpathians in Poland a zone of tectonized Miocene deposits crop out and this is distinguished as the Zgłobice Thrust Unit (ZTU, e.g. Kotlarczyk 1985, Połtowicz 1991, 2004, Krzywiec et al. 2004, 2014, Żelaźniewicz et al. 2011, Głuszyński \& Aleksandrowski 2016, and references therein). All the near-surface rock salt occurrences in the PCF, making a chain of separated salt bodies, are located within this tectonic unit. Salt-bearing strata 
have also been documented in boreholes drilled in the autochthonous Miocene both north of the Carpathian margin and below the Carpathian thrust-sheets, in the inner part of the foredeep (Garlicki 1968, Bukowski 2011), however, their spatial relationships with the shallow salt deposits in the ZTU are still not fully recognized.

The WSD defines the westernmost constituent of the salt chain in the ZTU. The salt bodies and salt-bearing strata extend there over a distance of ca $10 \mathrm{~km}$ and vary in width between a few hundred meters to ca $1.5 \mathrm{~km}$, whereas the depth of their occurrence varies from several tens of meters to $400 \mathrm{~m}$ below the ground surface.-

\section{THE LITHOSTRATIGRAPHY OF THE SALT-BEARING SUCCESSION}

The PCF was predominantly filled with synorogenic and postorogenic, mostly clastic, sediments in the Early and Middle Miocene. Their total thickness ranges between several hundred meters and ca $3.5 \mathrm{~km}$ in the outer part of the PCF and up to ca $1500 \mathrm{~m}$ in the inner part of the foredeep (Oszczypko 1998). The rock salt-bearing, evaporite succession was formed in the Middle Miocene, following the extensive marine transgression of the Parathethys Sea into the Carpathian Foredeep, starting in the early Badenian (Oszczypko et al. 2006). The sedimentary fill of the PCF in the vicinity of Wieliczka rests on a Mesozoic substratum and consists of three successive formations of uneven thickness, from base to top, being the Skawina, Wieliczka and Machów formations (Fig. 2).

The lowermost, Skawina Formation represents siliciclastic deposits, interpreted as deep sea sediments (Peryt 2006). They are overlain by an evaporite succession, itself comprising two, laterally equivalent formations (Alexandrowicz et al. 1982, Garlicki 1994): the Wieliczka Formation, dominated by chloride facies with interlayers of gypsum, anhydrite, claystones, shales and minor sandstones, and the Krzyżanowice Formation built of sulphate facies, i.e. mainly gypsum and anhydrite with interlayers of siliciclastic rocks (claystones, mudstones, sandstones and locally limestones). The increasing eastward total thickness of the Wieliczka Formation is estimated to vary between $\sim 40 \mathrm{~m}$ and more than $200 \mathrm{~m}$ (Garlicki 2008), with the thickness increasing eastwards. The thickness of the Krzyżanowice Formation is between $\sim 60 \mathrm{~m}$ in the marginal segments of the PCF and $\sim 10-20 \mathrm{~m}$ in its central part (Pawłowski et al. 1985). Garlicki (1979) distinguished altogether five cycles of the Badenian saliferous deposition in the PCF, annotated as I to V and the proposed models of their evolution. These cycles are, however, well distinguishable mainly in sediments of the autochthonous, outer part of the foredeep. A model of sulphate facies development was presented by Bąbel (2007 and references therein) as well as by Bąbel \& Boguski (2007). The models for both facies were also recently discussed by Bukowski (2011) and Głuszyński \& Aleksandrowski (2016). The two evaporitic formations are roughly coeval, although the sulphate formation is interpreted to have been deposited continuously since the beginning of the Paratethyan Badenian salinity crisis until its end, whereas the chloride facies were formed during the peak stages of the crisis and became mostly distributed in the southern part of the PCF (Garlicki 1979, Peryt 2006, Śliwiński et al. 2012). The time span of the evaporite succession deposition has been reliably determined with radiometric dating of rhyolite and andesite tuffs which underlie, are interlayered with and overlie the evaporate-bearing strata (details and references in Bukowski 2011 and Śliwiński et al. 2012). The investigations by de Leew et al. (2010) show that the salinity crisis in the PCF must have postdated $13.81 \pm 0.08 \mathrm{Ma}$ and the chloride precipitation started around $13.60 \pm 0.07 \mathrm{Ma}$. The chemical deposition and the Badenian salinity crisis ended before $13.45 \pm 0.06$ (de Leew et al. 2013), although Śliwiński et al. (2012) interpreted the duration of evaporite precipitation to continue till ca. $13.06 \pm 0.11 \mathrm{Ma}$. Thus, the Wieliczka and Krzyżanowice formations are Serravallian in age and correlate with the lower part of Nannoplankton Zone 6 (NN 6) in the Mediterranean (de Leew et al. 2010, 2013, Śliwiński et al. 2012, Bojar et al. 2018).

The evaporite formations are overlain by the siliciclastic-marly Machów Formation (Alexandrowicz et al. 1982). In the southern part of the present-day surface extent of the PCF, close to the Carpathian front, the basal part of the formation is distinguished as the Chodenice Beds and is composed of 200-300 m-thick series of claystones with interlayers of fine sandstones and marlstones. 


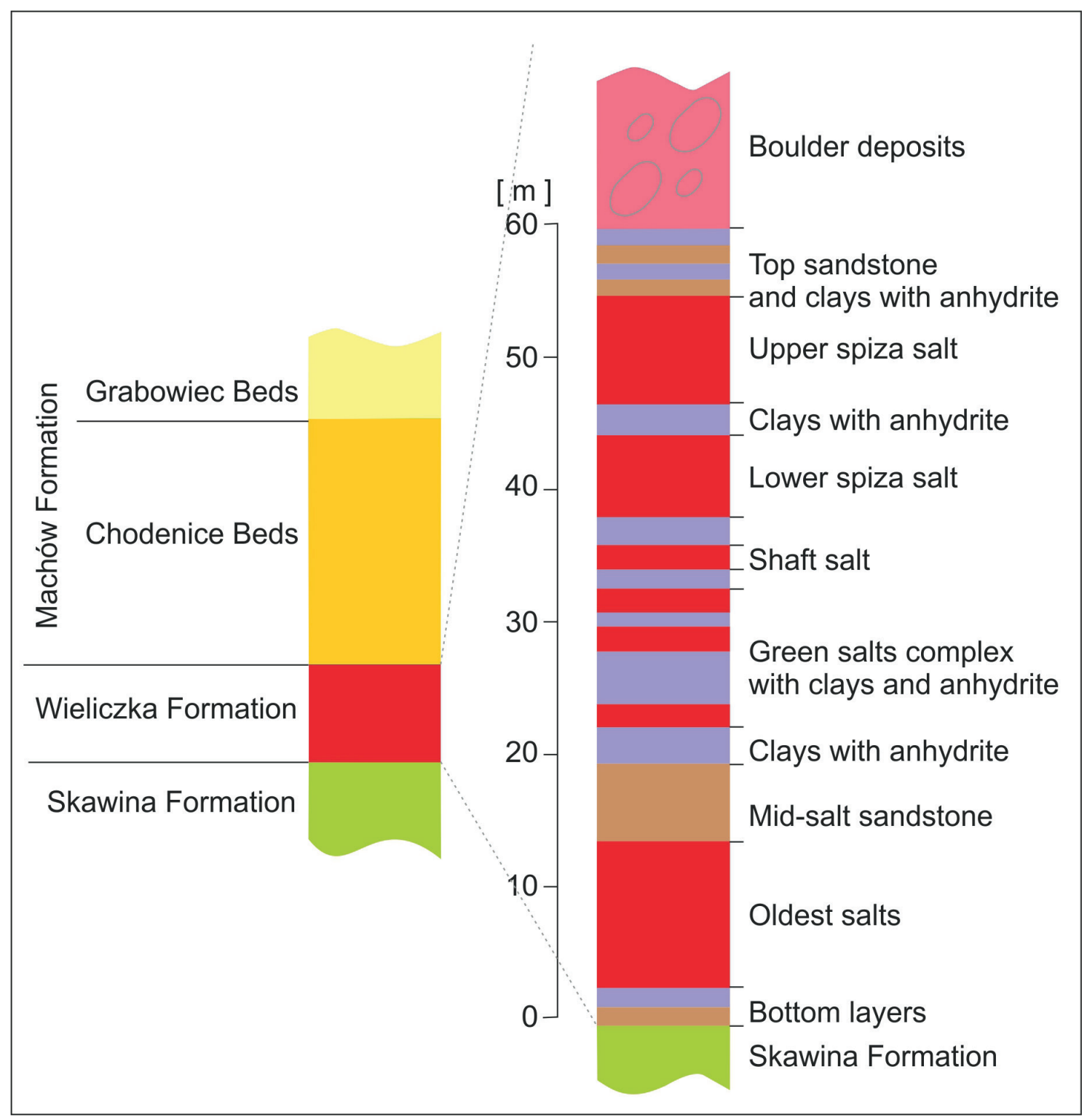

Fig. 2. Litostratigraphy of the WSD (after Wiewiórka et al. 2008, compiled after Gaweł 1962, Garlicki 1979, Wiewiórka 1988, Bukowski 2011)

Above them, the Grabowiec Beds occur, which is another 200-350 $\mathrm{m}$ thick, though coarser-grained clayey-marly-sandy series (Porębski \& Oszczypko 1999).

A detailed lithological profile of the salt-bearing succession in the vicinities of Wieliczka is shown in Figure 2. This is a local subdivision, incorporating historical terms originating over the course of centuries of mining. The salt-bearing deposits are traditionally divided into two main members (Gaweł 1962). The lower member, called stratified or bedded salt, is represented by various types of rock salt interlayered with anhydritic or salty claystones and siltstones, where the beds, although tectonized, maintain their original stratigraphic arrangement within large-scale tectonic structures. The upper member is termed boulder salt and predominantly consists of a mixture of claystones and salty claystones (the so called $z u$ ber) with blocks of rock salt, altogether not displaying visible stratification at the meso-scale.

There are five main rock salt litostratigraphic units within the stratified deposits (Fig. 2): (a) oldest salts (typically porphyric rock salt, with admixture and intercalations of clay, silt and sand), (b) green layered salts (consisting of five rock salt 
layers annotated as I-V, with anhydritic claystone intercalations), (c) shaft salt (relatively pure, coarse-grained rock salt, locally containing hydrocarbon inclusions), (d) lower- and (e) upper spiza salts, both coarse-grained rock salts, with intercalations of sandy anhydritic claystones. The oldest and green layered salts are separated by mid-salt sandstones, anhydritic claystones and siltstones, whereas the green layered salts, shaft salt, lower and upper spiza salts are separated predominantly by anhydritic claystones. The strata underlying and overlying the salt-bearing succession consist of anhydritic claystones and siltstones with intercalations of sandstones. According to Garlicki (2008), the bottom part of the succession, including the oldest salts, originated during the evaporite cycles I and II, the green layered, shaft and lower spiza salts formed during the cycle III, and the upper spiza salt during the cycle IV. The rock salt succession in the vicinity of Wieliczka is underlain by the topmost part of the Skawina Formation, built of claystones and referred to as subsalt claystones (Gaweł 1962, Garlicki 1979).

The boulder deposits above the stratified member contain blocks of different types of rock salt in clay mass. The rock salt in the blocks varies in grain size from fine- to coarse-grained, being laminated or with no visible lamination, displaying various shades of greenish, whitish or greyish colors. There are also blocks built of aggregates of large halite crystals mantled by clays, with some crystals containing a distinct chevron type structure. The size of blocks ranges from a few centimeters to tens of meters in diameter; they depict sharp boundaries with clays and are commonly rounded. The largest known block of rocks salt is estimated to be over $100,000 \mathrm{~m}^{3}$ in volume (Tarka 1992). In case the lamination is visible in clays, it may be either concordant or discordant with the layering in salt blocks. Boulder deposits are interpreted as originally shallow mudflat clay and salt sediments redeposited to a deeper part of the basin (Kolasa \& Ślączka 1985, Bukowski 1994, 2011, Ślączka \& Kolasa 1997). Redeposition and soft-sediment deformation was also documented in the stratified salt member and the effects of those processes are evidenced, among others, by the occurrence of salt conglomerates and breccias, liquefaction phenomena in clastic sediments, slumps, marlstone pebbles in salt layers, and admixture of carbonized flora material of terrestrial origin (Ślączka \& Kolasa 1997, Wagner et al. 2010, Bukowski 2011).

There exists some controversy as to the nature of the contact between the stratified and boulder members of the salt-bearing succession and the origin of the latter member. Kolasa \& Ślączka (1985) provided arguments in favor of a sedimentary origin of this deposit and of its boundary with the stratified member (e.g. the presence of redeposited material, with rock salt originated in various environments as well as cobbles and pebbles of Carpathian flysch rocks). On the other hand, Tarka (1992) documented small-scale tectonic structures and slickensides along this border in some locations and claimed the tectonic origin of the boundary and, thus, arguing for the tectonic origin of the whole boulder member. A tectonic origin for the boulder deposits was also postulated in earlier studies by Gaweł (1962), Poborski \& Skoczylas-Ciszewska (1963) and Połtowicz (1977).

\section{THE STRUCTURE OF THE WSD}

The tectonic deformation effects in the salt deposits of the Wieliczka area are not uniform in style. In the west, within the Barycz salt field, a folded salt series is thrust over the autochthonous salt at the front of the Carpathian flysch thrust wedge and, therefore, the salt deposits in this section are built of both autochthonous and allochthonous salts (Fig. 3). Along the westernmost section they are overridden by the Carpathians thrust sheets (i.e. tectonically overlain by the Carpathian flysch strata), whereas further east, the WSD is situated at the immediate front of the thrust sheets. Thus, the Outer Carpathian flysch front trends obliquely in this area to that of the salt deposit belt. The salt-bearing thrust unit is predominantly built of folded sequence, and thrusts are not distinctive in the tectonic structure. Another characteristic feature of the western segment of the WSD is that it is mostly composed of the stratified member and the boulder member is relatively thin in it (Gawel 1962, Poborski \& Skoczylas-Ciszewska 1963, Połtowicz 1977 and references therein, Wiewiórka 1988). 


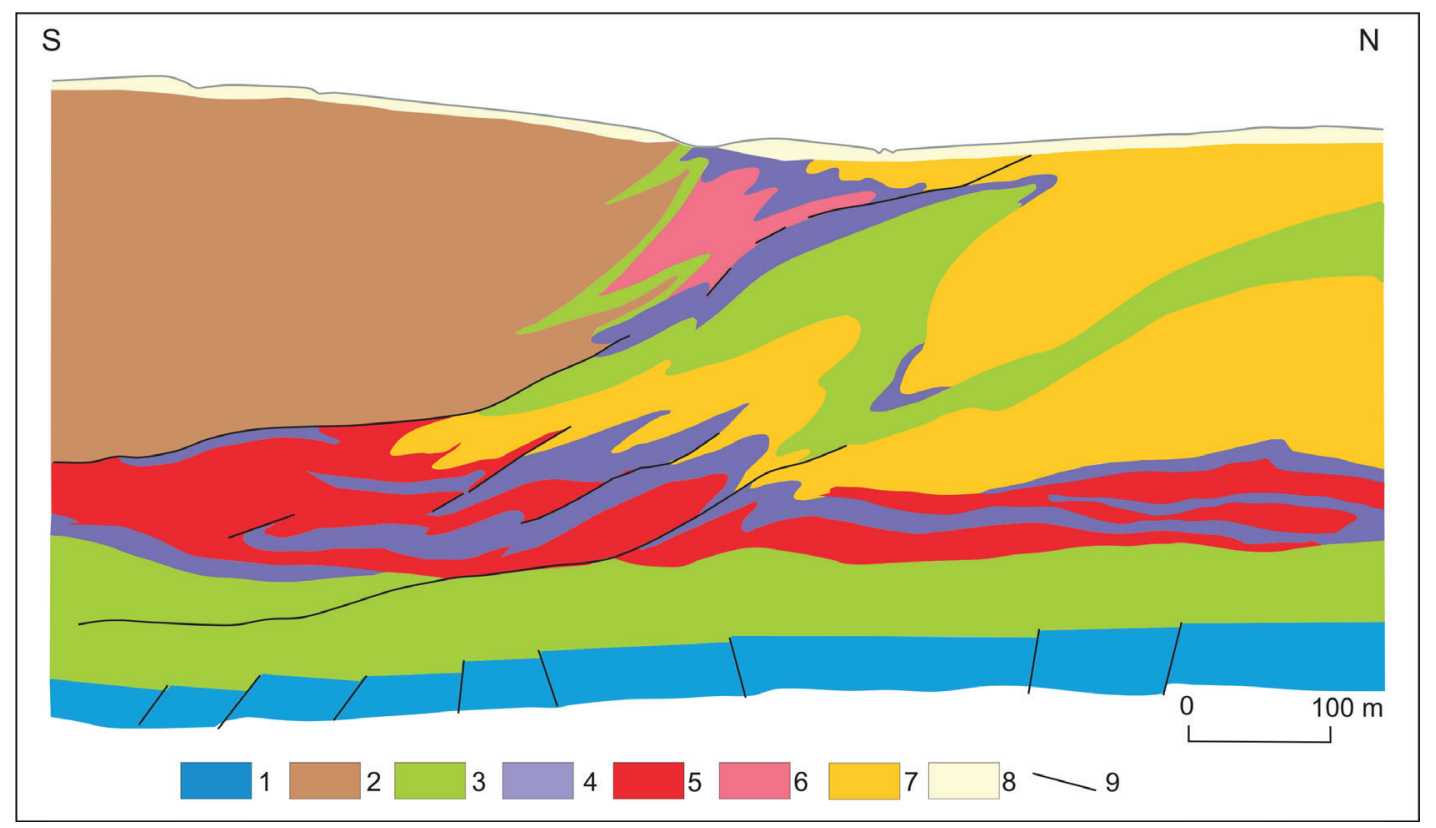

Fig. 3. Cross-section across the western part of the WSD (interpretation by Szybist, redrawn from Batko 1973, modified): 1 - Jurassic, 2 - Carpathian flysch, 3 - Skawina Formation, 4 - non-salt rocks in the salt succession (Krzyzanowice and Wieliczka formations), 5 - stratified salt member of the salt succession (Wieliczka Formation), 6 - boulder member of the salt succession (Wieliczka Formation), 7 - Chodenice Beds (Machów Formation), 8 - Quaternary, 9 - faults

The historical mining was concentrated in the central part of the WSD, in the direct vicinity of the town of Wieliczka, and, therefore, this part of the deposit is best recognized. The most comprehensive study on internal tectonic structure of the salt-bearing succession was carried out by Gaweł (1962), who presented numerous detailed maps and sections across the deposit (Fig. 4). In the following years, also other authors contributed to further recognition of both the internal structure and tectonic evolution of the WSD (Poborski \& Skoczylas-Ciszewska 1963, Garlicki 1968, 1979, Połtowicz 1977, Kolasa \& Ślączka 1985, Tarka 1992, Bukowski 1994, Ślączka \& Kolasa 1997, Cyran 2008). Based on those studies, it is known that the stratified portion of the salt deposit hosts three major thrusts: the northern, central and southern ones, separated by siliciclastic rock beds of the underlying Skawina Formation (Figs. 4, 5). The thrusts are, in general, southerly inclined at a moderate angle $\left(\sim 25^{\circ}\right)$, concordantly with the Carpathian frontal thrust (Tarka 1992).

Although the boulder member does not possess distinctive stratification, the elongated blocks of rock salt in clays do show a preferred orientation. Their longer diameters typically trend concordantly with the boundary with the stratified member and display variable plunge between $45^{\circ}$ and $75^{\circ}$ (Gaweł 1962, Cyran 2008). In the Wieliczka mine area, the thickness of the boulder and stratified members is generally comparable, whereas towards the east the boulder deposits become the main component of the salt-bearing succession (Szybist 1974, fide Cyran 2008).

The key problem which remained under discussion for a long time was the genetic relationship between the folded and overthrust stratified member and the overlying boulder member. According to the published cross-sections (e.g. Figs. 3-5), the boulder deposits are at least partly involved in the thrust-folding pattern of the stratified deposits. The salt-rich deposits of the stratified member apparently intrude the boulder member as tongue-like (sheath?) folds and the thrusts seem to propagate into or terminate within them. Because the boulder deposits are also folded in a similar style together with sulphate rocks above the rock salt-bearing units (Figs. 3-5), all these observations imply that the boulder member is a product of sedimentary processes, as interpreted by Kolasa \& Ślączka (1985) and it was deformed simultaneously with the stratified member due to the Carpathians pushing from the rear during the final overthrusting 
episode. The slickensides documented along the contact of the two members by Tarka (1992) point to the local activation of this lithological and, thus, a mechanical boundary during the thrusting.

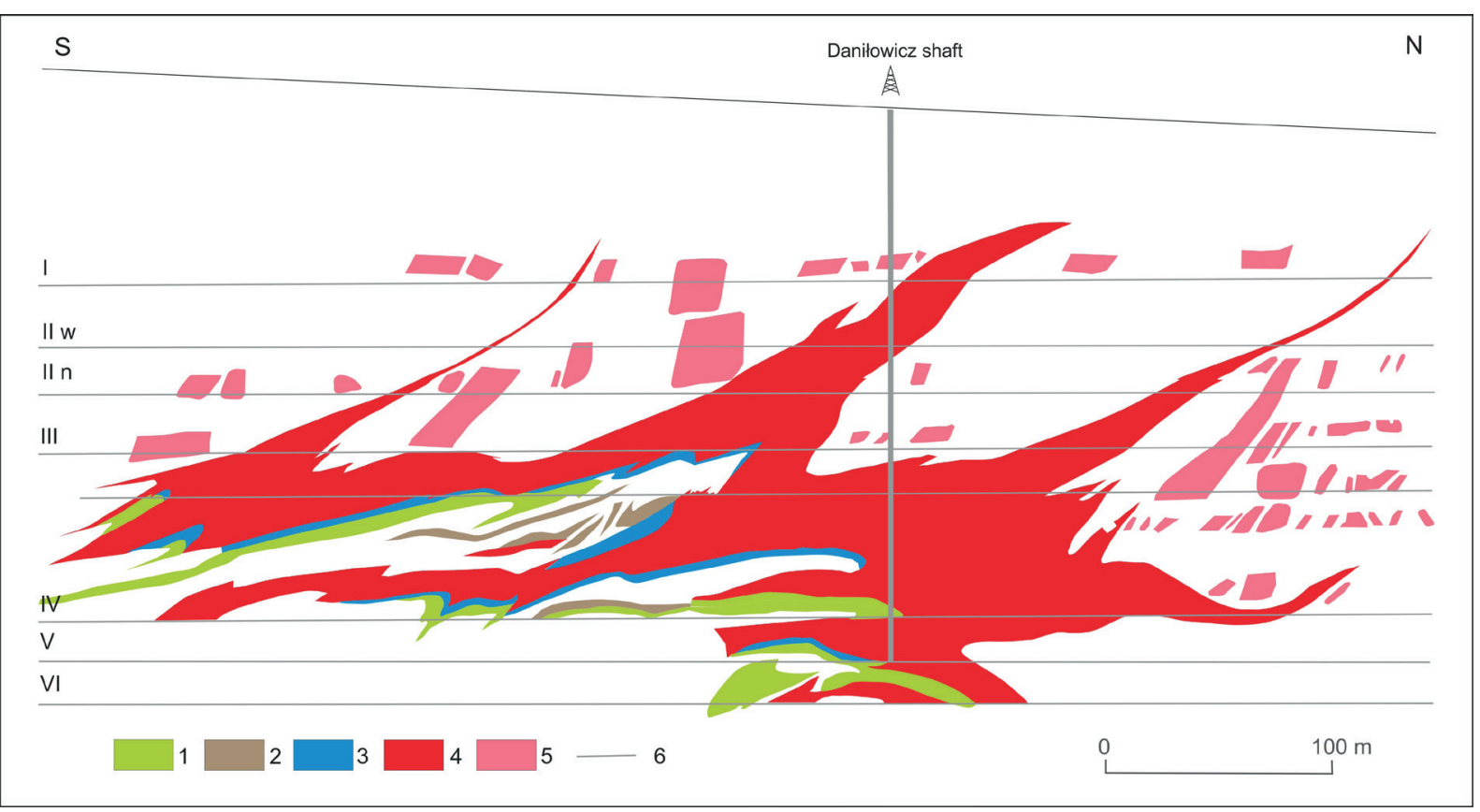

Fig. 4. Cross-section across the central part of the mining area in the WSD showing the distribution of selected rock salt types and excavated bodies of salt in the boulder salt member (after Gawet 1962, modified): 1 - green layered salts, 2 - mid-salt sandstone, 3 - shaft salt, 4 - spiza salts, 5 - excavated blocks of salt in boulder salt member. White color for non-salt deposits. Annotations I-VI - mining levels

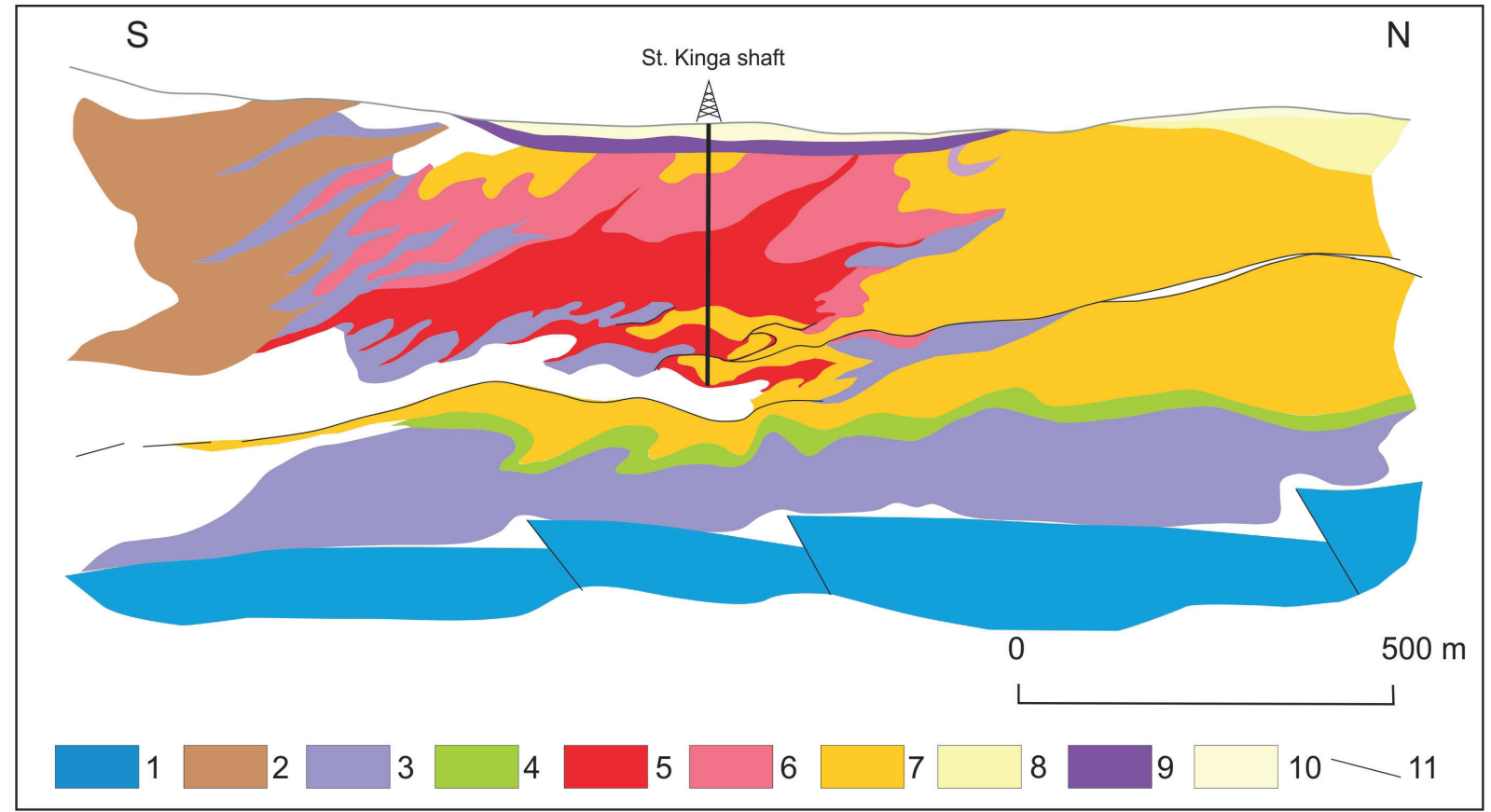

Fig. 5. Cross-section across the central part of the WSD (after Poborski 1965, fide Kuc 2016, modified): 1 - Jurassic, 2 - Carpathian flysch, 3 - sulphate rocks in Skawina, Krzyżanowice and Wieliczka formations, 4 - other rocks of Skawina Formation, 5 - stratified salt member of the salt succession (Wieliczka Formation), 6 - boulder member of the salt succession (Wieliczka Formation), 7 - Chodenice Beds (Machów Formation), 8 - Grabowiec Beds (Machów Formation), 9 - gypsum-clayey cap rock, 10 - Quaternary, 11 - faults 
Since the stratified member is lithologically heterogeneous and well stratified, being composed of alternating salts, claystones and sulphate rocks, abundant meso-scale tectonic structures have developed in this multilayer system in the course of tectonic deformation. These structures include folds of various dimensions and geometry (also superposed folds), thrusts and various systems of normal and reverse faults, boudinage, joints and veins (Gaweł 1962, Tarka 1992, Cyran 2008). Most of them display spatially consistent geometry and orientation of structural elements, indicative of evolution under roughly stable stress field conditions and consistently $\mathrm{N}-\mathrm{S}$ oriented direction of tectonic contraction (Tarka 1992, Cyran 2008). This direction is in line with that of the final stage of thrusting at the Carpathian orogenic front and, therefore, the tectonic structures in the salt-bearing succession can be interpreted as developed due to the push from the advancing Carpathian thrust wedge. However, as demonstrated originally by Kolasa \& Ślączka (1985) and Ślączka \& Kolasa (1997), there is a reliable record of gravity-driven redeposition and soft-sediment deformation preserved in the WSD. Although still related to the Carpathian orogenic wedge advancement, the direct factors responsible for the gravity-sliding, sediment redeposition and soft sediments deformation in front of the wedge were the topographic gradient at the sedimentary basin margin and increasing sediment load due to enhanced erosion of stacking sediments at the front of the Carpathians thrust sheets. These factors must have triggered the redeposition of Miocene sediments, their liquefaction, development of slumps and slides and a broad spectrum of deformation structures, such as slump folds, boudinage related to layer gliding and compressive tectonic structures in areas of slope gradient change. These early deformation structures were later superimposed by tectonic structures which developed during the thrusting and folding due to the compression exerted directly by the overthrusting Carpathian thrust sheets at the rear.

The salt-bearing succession also contains a record of brittle tectonic deformation, represented by joints, organized in spatially regular sets, and veins of epigenetic minerals (gypsum/anhydrite and halite), as well as effects of deformation related to phase transition between gypsum and anhydrite after sediment burial. The superposition of deformational structures, which originated at different evolutionary stages of the salt-bearing succession under the influence of various key factors, makes it quite challenging to distinguish between their particular generations. This seems to be the primary cause of variable interpretations and arguments on the WSD origin, structure and deformation.

For decades, one of the subjects of both study and discussion has been the mechanical role played by the Miocene PCF evaporites during the final phases of thrusting of the Outer Carpathians (e.g. Tołwiński 1956, see Krzywiec et al. 2004, 2012, 2014 for more detailed description). The Miocene foredeep strata became folded and thrust-faulted adjacent to the Carpathian front during that deformation stage, forming the marginal ZTU, where décollement and detachement surfaces were located in evaporite horizons (Oszczypko et al. 2006, Sieniawska et al. 2010). The forelandward advance of the orogenic wedge also led to the gradual northward shifting of the depocenter in the Miocene foredeep basin, and thus, coevally with the thrusting, a thick succession of synorogenic sediments accumulated in the outer PCF. At present, the WSD is piled up between the Carpathian front and the autochthonous deposits of the outer PCF.

Earlier tectonic models, prepared using drillhole and surface geological data, assumed a dominant role of the northward-directed thrusting in piling and pushing up the evaporites. A recent interpretation of high-quality seismic sections from the area located east of the WSD proved that within the zone characterized by the presence of relatively thick Miocene evaporites, including also rock salt, the Carpathian orogenic front is dominated by wedge tectonics, including backthrusting and the development of triangle zones (Krzywiec et al. 2004, 2012, 2014, Bukowski et al. 2010, Głuszyński 2014, Głuszyński \& Aleksandrowski 2014, 2015). By comparison with these seismic data, a similar tectonic model involving a triangle zone might be applied to the WSD (Fig. 6), following an earlier opinion of Jones (1997). 


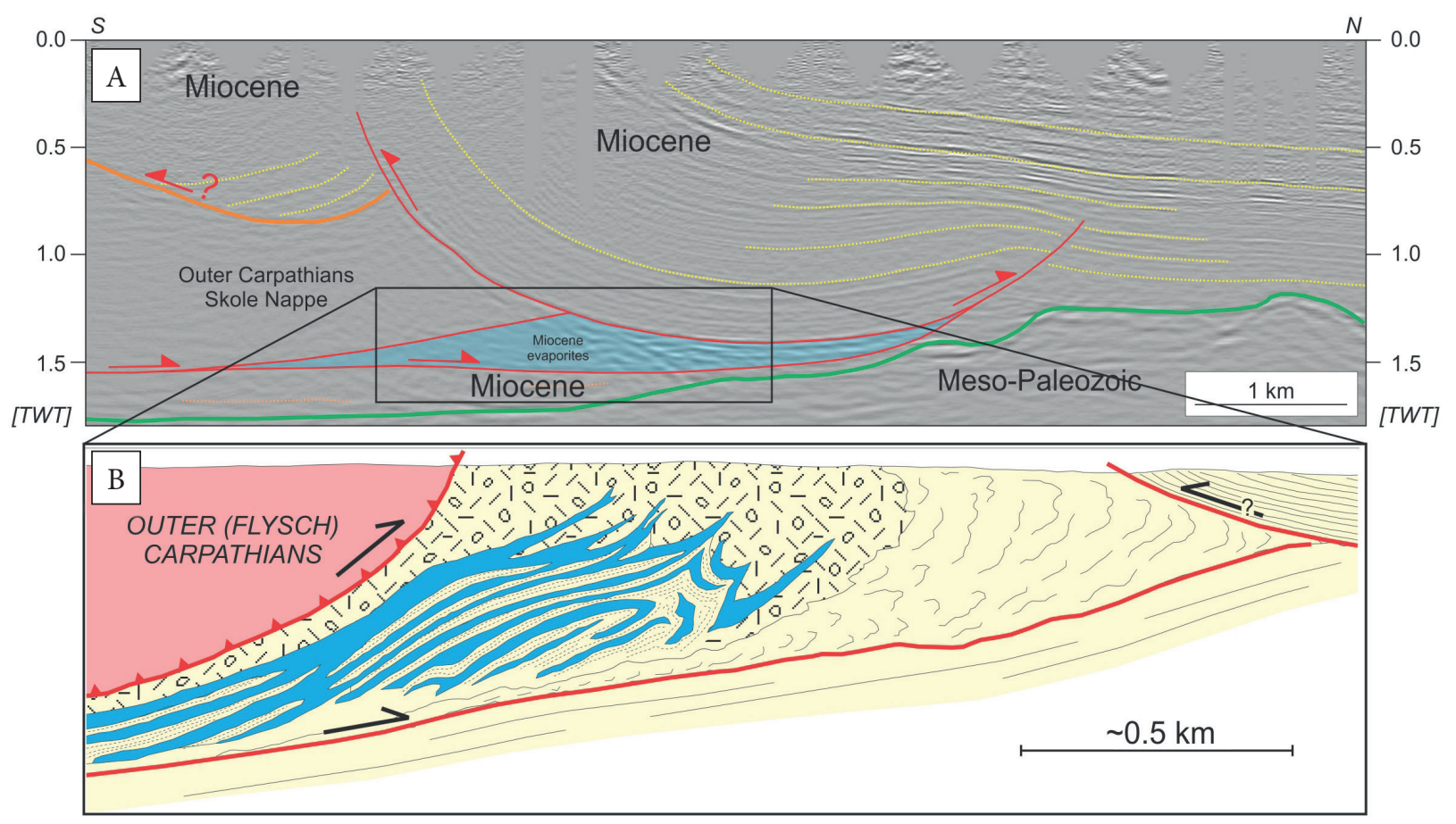

Fig. 6. Comparison of the Outer Carpathian orogenic front (A) in the Pilzno area (from Krzywiec et al. 2014) and (B) in the Wieliczka area (cross-section redrawn from Totwiński 1956, modified). In both cases, the presence of the Miocene evaporites triggered substantial backthrusting and the formation of the triangle zone

The thick mass of salt rocks in the WSD must have accumulated not only through squeezing the salt from below the northward thrusting Carpathian flysch wedge but also in response to loading the foreland with a thick synorogenic sedimentary succession of the Chodenice and Grabowiec formations, which eventually disabled the forelandward propagation of the Carpathian thrusts, and triggered the backthrusting of the Miocene strata. The thick mass of rock salt-bearing evaporites of the WSD constitutes the core of the thus formed triangle zone at the front of the Carpathian thrust belt. The validity of such an interpretation is supported by results of analyses of seismic sections in other parts of the PCF and by analogue modelling (e.g. Sieniawska et al. 2010, Głuszyński \& Aleksandrowski 2016).

\section{CONCLUSIONS}

The WSD is composed of Miocene (Badenian/ Serravallian) evaporite-siliciclastic succession deposited in the Carpathian foreland basin and later variously affected by tectonism at the front of the approaching Carpathian thrust wedge. This neighborhood influenced both the syn-orogenic sedimentary facies development and distribution, as well as the subsequent deformation of the sediments. The effects of two main stages of deformation can be distinguished in the rocks exposed in the Wieliczka Salt Mine. These are the products of gravity-driven, soft-sediment deformation, and those of tectonic deformation related to the northward thrusting of the Carpathian orogenic wedge, superimposed on the former. Both are represented by abundant largeand small-scale tectonic structures developed in the salt-bearing strata. Since both the sediment gravity gliding leading to redeposition of sediments in the Carpathian foredeep and the thrust displacements of the Carpathian orogenic wedge were towards the north, the structures formed at different stages of tectonic evolution do not differ significantly in orientation, often making it difficult to distinguish between those originated at the early and those formed at the late evolutionary stages of the Carpathian foredeep margin. 


\section{FIELD EXAMPLES}

Below, selected problems of the WSD geology are reviewed in reference to exposures available in the
Wieliczka salt underground mine level 2, which will be visited during the CETEG $16^{\text {th }}$ Meeting field session. An approximate location of the particular field session sites is presented in Figure 7.

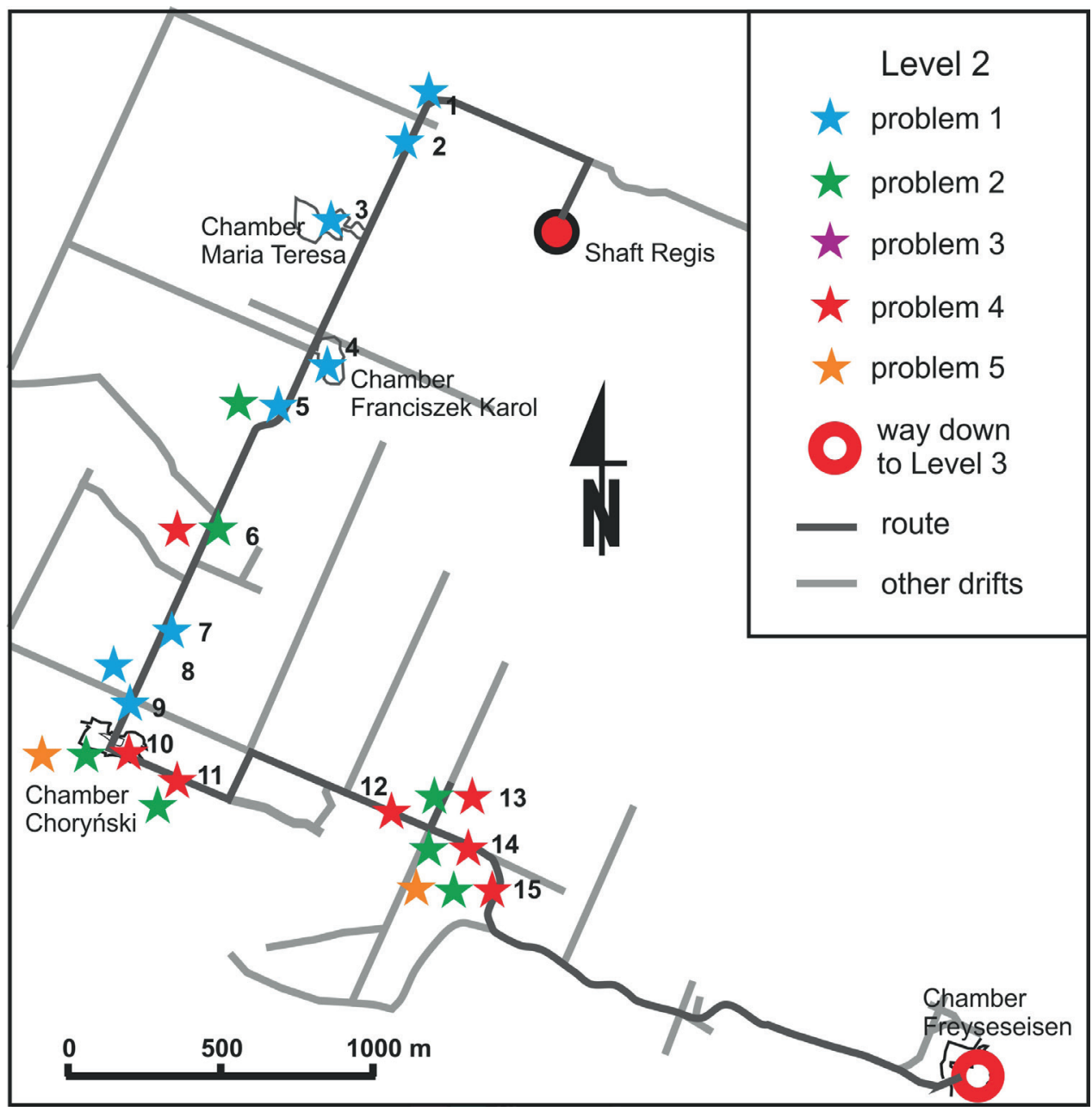

Fig. 7. Approximate location of phenomena discussed in the text on a sketch map of the Wieliczka mine level 2

PROBLEM 1: Geology of the boulder salt member

Sites: 1, 2, 3, 4, 5, 7, 8

Location: $2^{\text {nd }}$ mine level

The discussion on the origin of the boulder salt member has focused on a question whether it had formed in response to tectonic (Gaweł 1962, Poborski \& Skoczylas-Ciszewska 1963, Połtowicz 1977, Tarka 1992) or sedimentary factors (Kolasa \& Ślączka 1985, Bukowski 1994, 2011, Ślączka \& Kolasa 1997). The member consists of clays and boulders of two dominant types of rock salt: the green boulder salt, typically layered, and so called stained glass salt - with its name due to the fabric the salt displays, being made up of relatively big (up to over $10 \mathrm{~cm}$ ), pure halite crystals coated with clays (Fig. 8). The crystals in the latter salt type are subhedral, elongated to irregular, thus, the salt fabric cannot be unequivocally explained with any single geological process. However, since only some crystals depict a chevron structure, with growth rims visible with a naked eye (Fig. 8D), it can be concluded that this type of salt is a mixture of halite that had crystallized in various environments and subsequently became redeposited and mixed with clays. 

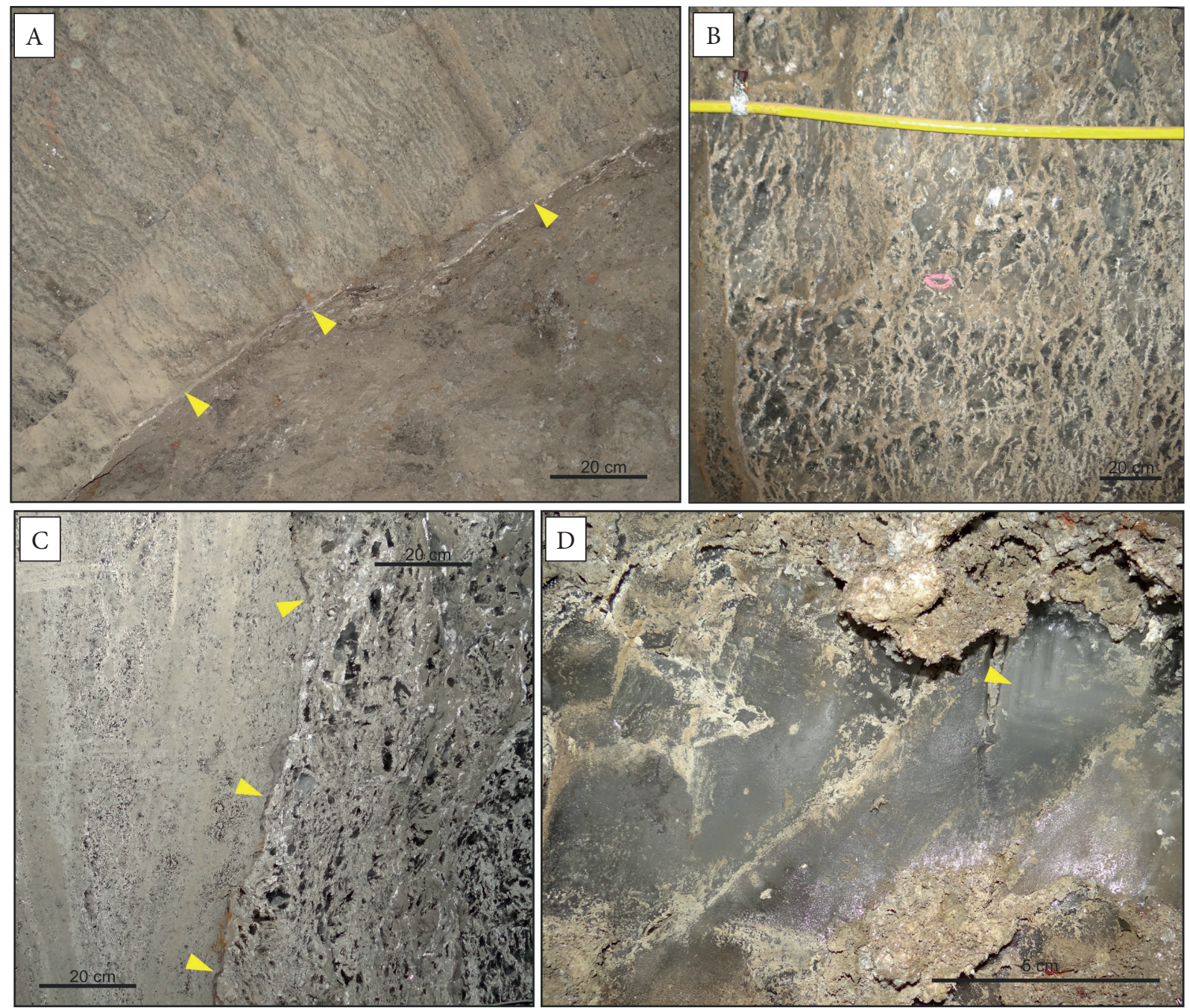

Fig. 8. Geology of the boulder salt member: A) a contact between a green layered-salt boulder and claystone; B) a glass-stained salt boulder composed of large halite crystals coated by claystone; $C)$ a contact between two boulders consisting of different salt types; D) an example of chevron halite in the glass-stained salt

The salt layering in boulders is either consistent with or oblique to that in clays, and at some locations, a veneer of epigenetic, granular or fibrous halite appears along the contact. Veins of epigenetic halite of various types (including fibrous) are common in clays. All these observations are in favor of the sedimentary origin of the boulder salt and its subsequent semi-brittle to brittle deformation due to compression in front of the approaching Carpathian thrust wedge. However, open questions still remain: since the size of the largest boulders is measured in tens of meters (estimated e.g. in chambers dug out in single salt boulders, such as the famous Maria Teresa or Franciszek Karol chambers or the St. Kinga Chapel), what were the sedimentary environments and processes which made an accumulation of such a thick salt package possible, together with its subsequent disintegration into blocks, and what, if any, was the role of tectonics in it.

\section{PROBLEM 2: Stratified salt member} and its boundary with boulder salt

Sites: $5,6,7,10,11,13,14,15$

Location: $2^{\text {nd }}$ mine level

There is also a controversy about the origin of the stratified salt member and the nature of its contact with the boulder member. The stratified salt member consists of five lithostratigraphic salt units (Fig. 2), originated during cyclic evaporation in the Badenian (Garlicki 1979, 2008). 
However, Kolasa \& Ślączka (1985) and Ślączka \& Kolasa (1997) showed evidence for redeposition of some lithified salt beds, and expressed and opinion that the lower and upper spiza salts are redeposited sediments. The stratified salt member is mostly composed of various types of rock salt, interlayered with anhydritic claystones, shales and sandstones and it hosts a wide range of tectonic structures, including folds and thrusts (Fig. 9). It is, therefore, contrastingly different in structure to the boulder member, which has led to mutually opposing interpretations of their contact.
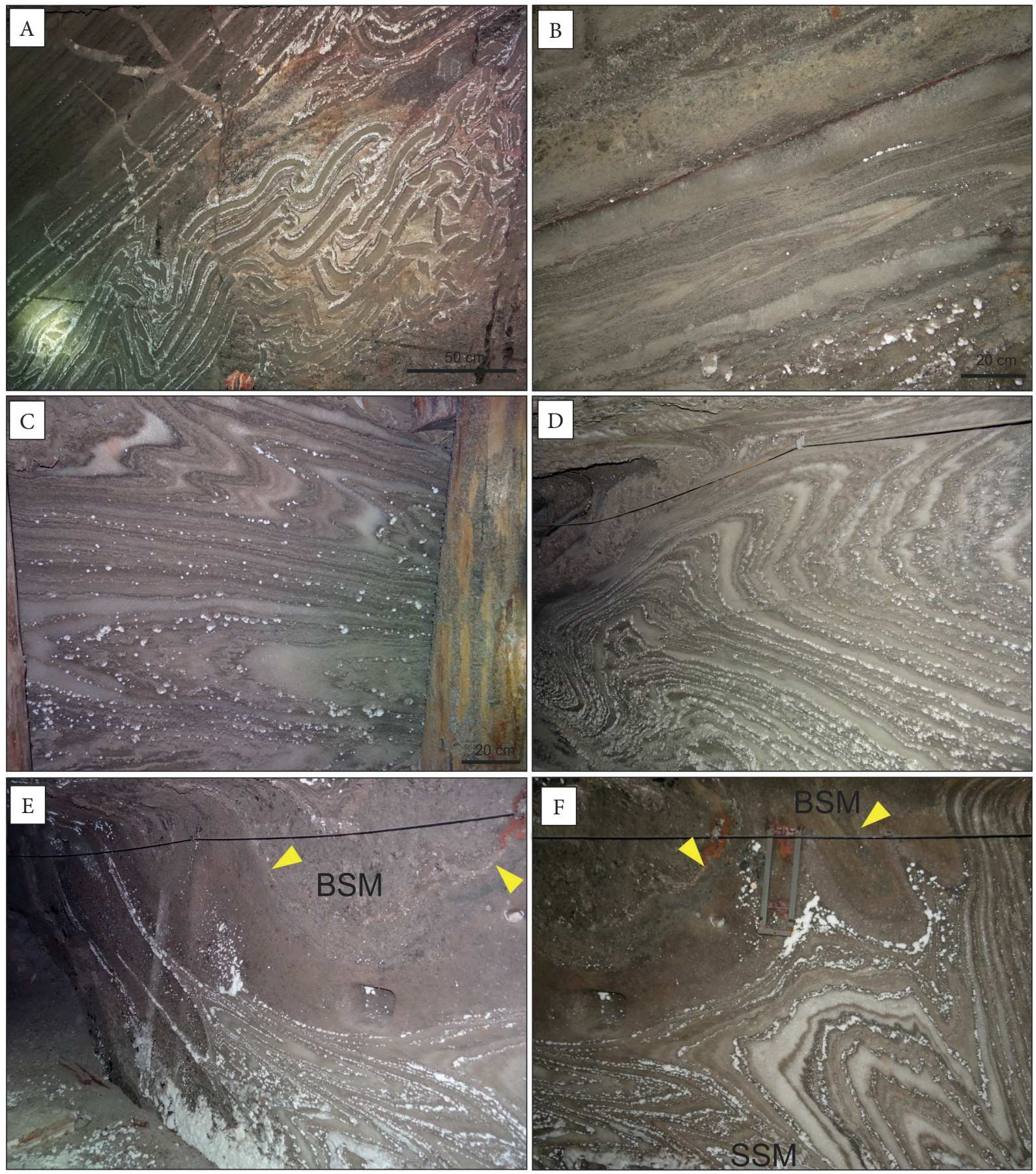

Fig. 9. Geology of the stratified salt member and its contact with the boulder salt member: A) lithological heterogeneity of the stratified member enabled development of a wide variety of meso-scale structures, indicative of ductile and brittle mechanisms of deformations; B)-F) folds in rock salt, originated and shaped during progressive deformation; $E, F-a$ folded contact between the stratified salt (SSM) and boulder salt (BSM) members 
Slickensides documented e.g. by Tarka (1992) in now inaccessible galleries, were used as an argument for the tectonic nature of the contact. Currently, available sections show that the contact is locally folded and the rock salt intrudes into clayey salt as narrow folds with extremely thinned out noses, or along thrust planes (Fig. 9). Such an arrangement implies that the two members have deformed together and, thus, their boundary is of sedimentary origin. Epigenetic halite veins also occur locally along the contact, commonly depicting a fibrous structure, and therefore it is possible that casts of halite fibres were misinterpreted as slickensides in other locations. However, the tectonic displacement along the contact could occur locally.

Meso-scale folds in rock salt display a variety of shapes and dimensions (Fig. 9). The axial planes of most folds are inclined concordantly with an overall inclination of strata, dipping mainly southward (and locally northward) at variable angles, between $0^{\circ}$ and $90^{\circ}$. This, together with varying bed strike in a map scale, points to control of large-scale tectonic structures on meso-scale fold geometry. The majority of minor folds are tight, isoclinal and often of sheath-fold characteristics Box, fan and superimposed folds also occur, the latter being most commonly open. Due to lithological heterogeneity and the variability of layer thickness, folds are dominantly disharmonic (Fig. 9).

\section{PROBLEM 3: Carpathian flysch sediments in the salt succession \\ Site: 8 \\ Location: $2^{\text {nd }}$ mine level}

The timing of deformation in the salt deposit has remained far from being precise. The main episodes of deformation took place in the late Badenian during the deposition of the salt succession (primarily gravity driven deformation) and probably ended in the Sarmatian during or prior to the deposition of the Grabowiec Beds, since the latter unit is not involved in Carpathian thrusting and overlies the partly deformed Wieliczka Formation and Chodenice Beds. The presence of Carpathian flysch rock bodies within the boulder salt member (Fig. 10) suggests that the tectonization of the salt succession was contemporaneous with the northward advancement of the nearby orogenic wedge.
The structural geometry and dimensions of flysch bodies in the Wieliczka salt deposit are not known. These are mostly marls and clays, interpreted as olistoliths by Kolasa \& Ślączka (1985) and Ślączka \& Kolasa (1997) and containing Turonian-Campanian foraminiferal assemblages (Machaniec \& Zapałowicz-Bilan 2005). The accessible mine gallery sections indicate that the flysch fragments became deformed together with the boulder salt deposits (Fig. 10).

The influence of the advancing orogenic wedge and northward migration of the southern basin margin is reflected in the lithology of the uppermost spiza salt units. The rock salt is silt- and sand-rich and contains admixtures of coalified flora. The geochemical characteristics of the coals implies their wood fire origin (Wagner et al. 2008) and the coaly material highlights the folded internal structure of the salts (Fig. 10). The geometry of the folds is typical of flow folds with superposed shearing and they document soft-sediment deformation of water saturated sediments, probably representing slump folds.

\section{PROBLEM 4: Rheology of the salt complex during deformation}

Sites: $6,9,10,11,12,13,14,15$

Location: $2^{\text {nd }}$ mine level

The most spectacular sets of deformation structures are developed in lithologically heterogeneous rock units, consisting of interlayering rock salts, anhydritic clays, shales and sandstones, i.e. in the green salt and upper and lower spiza salt units. In almost every exposure a structural record of both ductile and brittle deformation (folds, faults boudinage, veins, and joints) is encountered, indicative of changes in rheological properties of rocks during the structural evolution of the WSD structure. The style of deformation is obviously linked with competence or viscosity contrasts between the layers, as well as with the layer thickness. However, even individual layers may display variable deformation along their extent. For example, relatively thick (from $1 \mathrm{~cm}$ to $>100 \mathrm{~cm}$ ) sandstone and anhydritic claystone layers embedded in salt, developed classical boudinage, book shelf structures, boudins' imbrication and folding of boudinaged layers (Figs. 9, 11). 

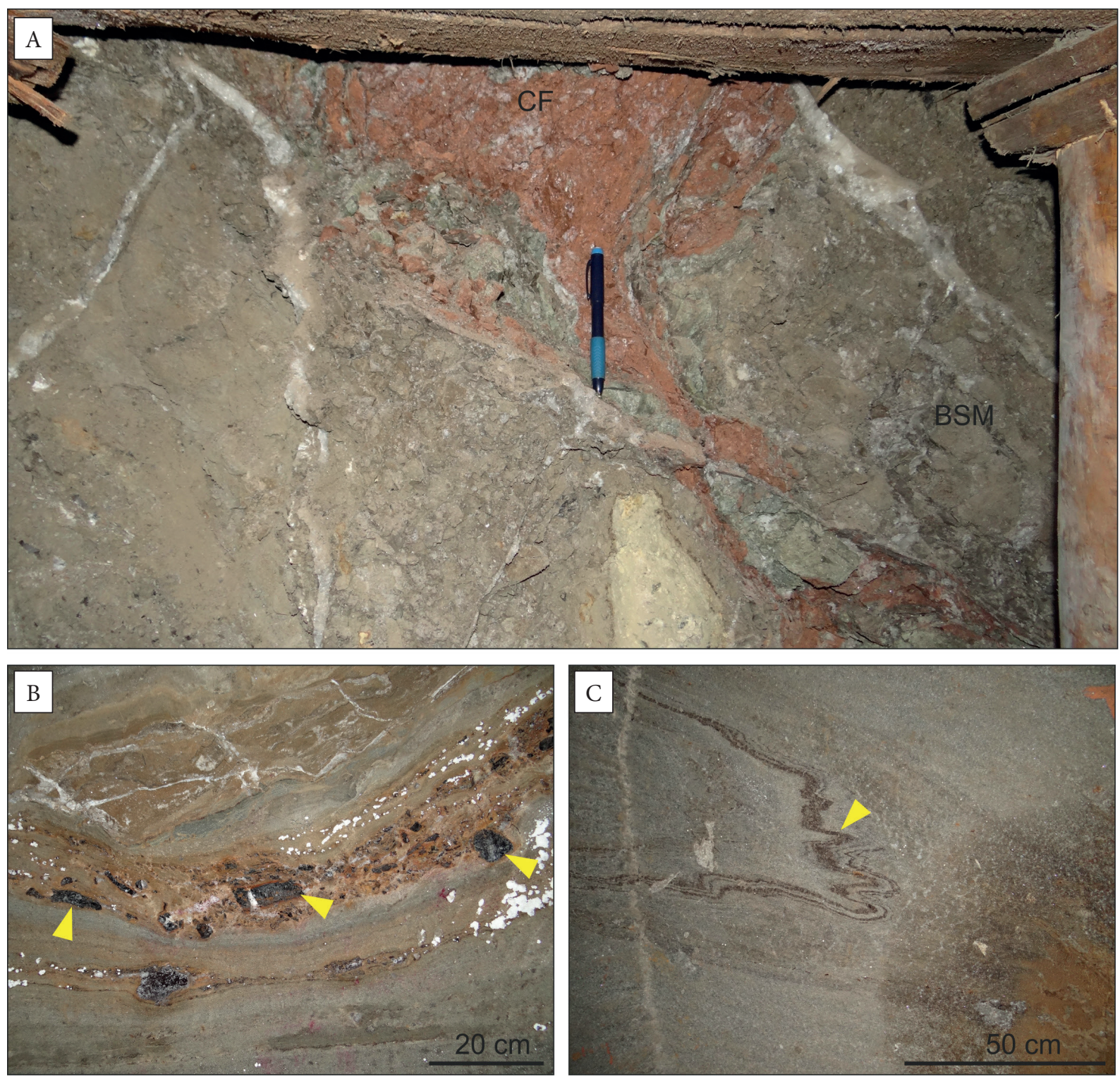

Fig. 10. Carpathian material in salt bearing strata in Wieliczka: A) flysch rocks (CF) in the boulder salt member; B) coaly material (dark colour) in salt strata; $C$ ) coalified flora (dark colour) delineates layering in salt

The boudinage of anhydritic claystone layers in folded salts reveals complex patterns, with e.g. imbricated and folded boudins in fold limbs and hinges (Fig. 11). Typically, the colour of rock salt adjacent to boudins is whitish, suggesting that the salt is of secondary origin, free of clay and anhydrite admixtures. The reported observations indicate progressive deformation of layers, starting with boudinage developed due to layer stretching, then followed by shearing and folding. The boudinaged layers may then have undergone thrusting and normal or reverse faulting in other segments of the layers. The resultant structures can be traced both along the N-S sections, i.e. orthogonally to the layers' strike (and in line with the gravity-driven and orogenic-related transport directions), as well as in the $\mathrm{W}-\mathrm{E}$ sections, i.e. along-strike. The boudinaged layers traced in N-S sections display folding, imbrication and piling up of boudins, dominantly in larger-scale folds' hinges, with northward vergence. The along-strike cross-sections reveal folds of boudinaged and faulted layers displaying flattened elliptical or lenticular shapes, pinching out sideways and separated with layers without clear deformation features (Fig. 11E). 

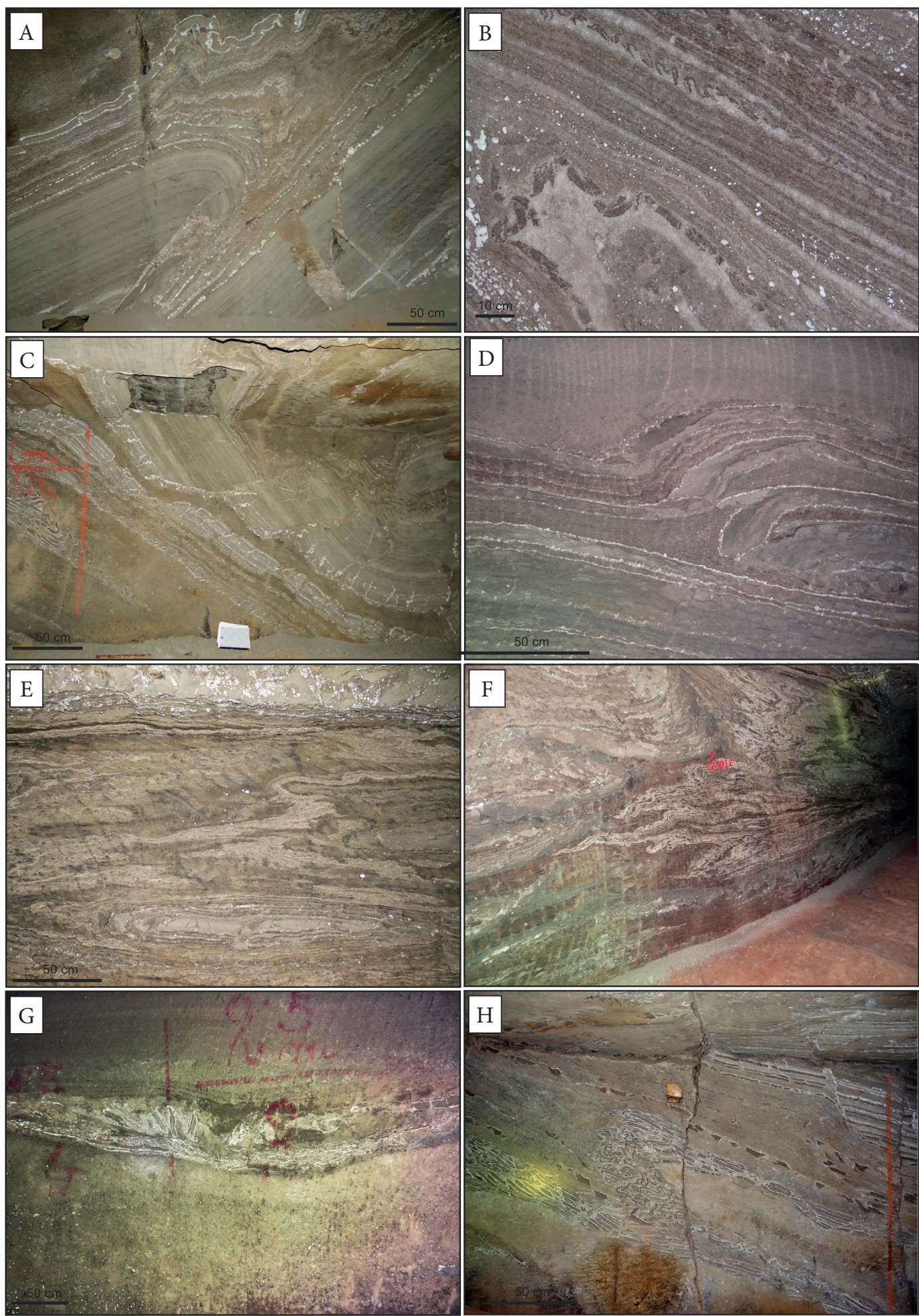

Fig. 11. The role of rheological variation in the salt succession is demonstrated by the varying styles of deformation of layers, being primarily dependent on the competence or viscosity of individual layers and sets of layers, their thickness and location in large-scale tectonic structures: A) progressive deformation of a sandstone and claystone layers: they are both boudinaged, folded and thrusted over themselves; halite veins document the latest stages of deformation; B) boudins of anhydritic-claystone layers in a hinge of a fold in rocksalt; $C$ ) boudinage around a large-scale synform; D) overthrusting clay-and sand-rich layers in an along-strike view; E)-G) along-strike (relative to the extent of the WSD) view of deformational structures: $E$ - folds are elliptical in shape; $F$ - folds in intercalating layers of relatively low competence contrast depict subordinary flame-like folding in hinges; $G$ - domains with deformed layers typically display lenticular shape, resembling channel fills, slump or slide lobes in a cross-section; H) imbricated boudins typically pile up in hinges of northward verging folds 
In case of layers with less contrasting competence, the elliptical and flattened folds are complexly folded at sideway hinges, with minor folds resembling flame-like patterns at the contact with the adjacent rock salt (Fig. 11F).

The properties of rock salt during deformation are enigmatic, as intensely folded layers of recrystallized halite may neighbour rock salt layers containing relics of primary sedimentary structures and textures. Large amplitude vs. width ratios of folds in rock salt (in some cases the ratio exceeds 20) and the ability of salt to intrude the boulder salt member along thrusts planes, imply the high mobility of salt. Because there is no indication of the deep burial of the salt deposits, the low viscosity of the rock salt must have been due to the high water content in the rock (cf. Talbot \& Jarvis 1984, Talbot et al. 2000, Urai et al. 2008). Secondary crystallization of rock salt around anhydritic-claystone boudins or in fold hinges, as well as dewatering structures in sand-rich layers adjacent to salt layers confirm this conclusion. A high content of water in the sediments can also be inferred from irregular contacts of some relatively pure salt layers with claystones or clay- and sand-rich rocksalt, being indicative of the partial dissolution of those pure salt layers and their emplacement as slabs or slices into clayey or sandy sediments. Summing up the observations, the sets of mezo-scale tectonic structures point to the deformation of the salt succession under high water saturation and northward directed flow or gliding of beds. The lenticular geometry of deformed layer stacks in along-strike sections of the mine galleries implies that they have formed due to gravitational, downslope, progressive advancement of lobes of submarine slumps or slides.

The flow of salt in sediments on basin slopes is documented in several locations worldwide, e.g. in the Gulf of Mexico and Red Sea (e.g. Hudec \& Jackson 2006, Feldsen \& Mitchell 2015). These modern environments may serve as equivalent settings both in respect to sedimentary and early deformational evolution of the WSD. However, since most of the observable meso-structures in the WSD are due to soft-sediment deformation, a question arises: what is the meso-structural record of the tectonic strain related to the overthrusting Carpathians? Apart from overall reorientation of strata (from northward dipping to southward dipping) and thrusts and folds documented on cross sections at a map scale, the only apparent meso-scale tectonic structures are halite and anhydrite veins, and joints. The halite veins are fibrous or granular in texture and they either cross-cut earlier deformed strata or follow fault or thrust surfaces, thus possibly being related to their reactivation.

\section{PROBLEM 5: Veins}

\section{Sites: $10,15,16$}

Location: $2^{\text {nd }}$ and $3^{\text {rd }}$ mine levels

Anhydrite and halite veins developed at various stages of deformation and they document changes in the geochemistry of fluids circulating in the WSD. The older sets of veins are built of fine-grained anhydrite. They are both oblique and parallel to layering. In many locations, these veins display apparent folding, with the style of folds resembling those of ptygmatic folds or, more commonly, enterolithic folds. Although the bedding-parallel veins of anhydrite look like sedimentary layering, their mineralogical purity and only local occurrence imply their epigenetic origin (Fig. 12).

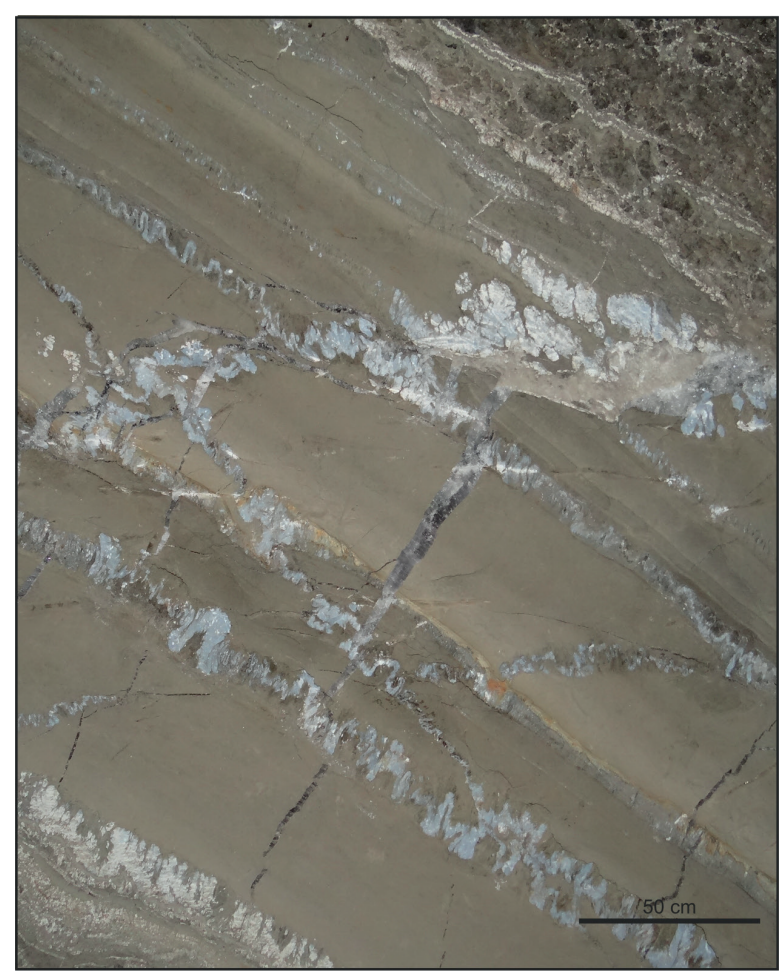

Fig. 12. Set of anhydrite veins internally deformed due to phase transition between anhydrite and gypsum 
The exposed surfaces of veins show cuspate-lobate morphology. Thus, such a style of anhydrite veins must have resulted from the phase transition between anhydrite and gypsum, i.e. from the increase in volume of hydrated anhydrite, by even up to $61 \%$ (Pettijohn 1975). Although which of the two sulphate minerals originally precipitated in the sedimentary basin is not known, the phase transition between them must have taken place at least twice, as at present the veins are built of anhydrite again. Therefore, the anhydrite veins also bear a record of the progressive variation in the depth of burial of the WSD strata, due to loading with a thick synorogenic succession derived from the northward thrusting Carpathians followed by erosional unloading during the uplift and inversion of the Miocene basin.

Halite veins are typically fibrous, showing the antitaxial growth of fibres and their relatively consistent orientation in similar sets of veins over large areas. Thus, the majority of halite veins must have developed during the latest stages of the WSD tectonic deformation. Less common are mineralogically composite veins with two or only one wall built of anhydrite and with fibrous halite in the core or aside, respectively.

\section{REFERENCES}

Alexandrowicz S., Garlicki A. \& Rutkowski J., 1982. Podstawowe jednostki litostratygraficzne miocenu zapadliska przedkarpackiego. Kwartalnik Geologiczny, 26, 470-471.

Bahroudi A. \& Koyi H.A., 2004. Tectono-sedimentary framework of the Gachsaran formation in the Zagros Foreland basin. Marine and Petroleum Geology, 21, 1295-1310.

Bąbel M., 2007. Depositional environments of a salina-type evaporite basin recorded in the Badenian gypsum facies in the northern Carpathian Foredeep. [in:] Schreiber B.C., Lugli S. \& Bąbel M. (eds.), Evaporites Through Space and Time, Geological Society Special Publications, 285, Geological Society, London, 107-142.

Bąbel M. \& Bogucki A., 2007. The Badenian evaporite basin of the northern Carpathian Foredeep as a model of a meromictic selenite basin. [in:] Schreiber B.C., Lugli S. \& Babel M. (eds.), Evaporites Through Space and Time, Geological Society Special Publications, 285, Geological Society, London, 219-246.

Bojar A-V, Barbu V., Wojtowicz A., Bojar H-P, Hałas S. \& Duliu O.G., 2018. Miocene Slănic Tuff, Eastern Carpathians, Romania, in the Context of Badenian Salinity Crisis. Geosciences, 8, 73, 1-13. DOI:10.3390/geosciences8020073.
Bukowski K., 2011. Badeńska sedymentacja salinarna na obszarze między Rybnikiem a Dębica w świetle badań geochemicznych, izotopowych i radiometrycznych. Rozprawy Monografie, 236, Wydawnictwa AGH, Kraków.

Bukowski K., de Leeuw A., Gonera M., Kuiper K.F., Krzywiec P. \& Peryt D., 2010. Badenian tuffite levels within the Carpathian orogenic front (Gdów-Bochnia area, Southern Poland): radio-isotopic dating and stratigraphic position. Geological Quarterly, 54, 4, 449-464.

Burliga S., Koyi H.A. \& Krzywiec P., 2012. Modelling cover deformation and decoupling during inversion, using the Mid-Polish Trough as a case study. Journal of Structural Geology, 42, 62-73. DOI: 10.1016/j.jsg.2012.06.013.

Carrillo E., Koyi H.A. \& Nilfouroushan F., 2017. Structural significance of an evaporite formation with lateral stratigraphic heterogeneities (Southeastern Pyrenean Basin, NE Spain). Marine and Petroleum Geology, 86, 1310-1326.

Callot J.-P., Trocmé V., Letouzey J., Albouy E., Jahani S. \& Sherkati S., 2012. Preexisting salt structures and the folding of the Zagros Mountains. [in:] Alsop G.I., Archer S.G., Hartley A.J., Grant N.T. \& Hodgkinson R. (eds.), Salt Tectonics, Sediments and Prospectivity, Geological Society Special Publications, 363, Geological Society, London, 545-561.

Cartwright J., Jackson M., Dooley T. \& Higgins S., 2012. Strain partitioning in gravity-driven shortening of a thick, multilayered evaporite sequence. [in:] Alsop G.I., Archer S.G., Hartley A.J., Grant N.T. \& Hodgkinson R. (eds.), Salt Tectonics, Sediments and Prospectivity, Geological Society Special Publications, 363, Geological Society, London, 449-470.

Cobbold P.R., Szatmari P., Demercian L.S., Coelho D. \& Rossello E.A., 1995. Seismic and experimental evidence for thin-skinned horizontal shortening by convergent radial gliding on evaporites, deep-water Santos Basin, Brazil. [in:] Jackson M.P.A., Roberts D.G. \& Snelson S. (eds.), Salt Tectonics: A Global Perspective, American Association of Petroleum Geologists Memoir, 65, AAPG, 305-321.

Cotton J.T. \& Koyi H.A., 2000. Modeling of thrust fronts above ductile and frictional detachments: Application to structures in the Salt Range and Potwar Plateau, Pakistan. Geological Society of America Bulletin, 112, 3, 351-363.

Cyran K., 2008. Tektonika mioceńskich złóż soli w Polsce. Archiwum Wydziału Geologii Geofizyki i Ochrony Środowiska, AGH, Kraków [Ph.D. thesis].

Davis D. \& Engelder T., 1985, The role of salt in fold-andthrustbelts. Tectonophysics, 119, 67-88.

Feldens P., Mitchell N.C., 2015. Salt Flows in the Central Red Sea. [in:] Rasul N.M.A. \& Stewart I.C.F. (eds.), The Red Sea, Springer Earth System Sciences, Springer-Verlag, Berlin - Heidelberg, 205-218. DOI: 10.1007/978-3-66245201-1_12.

Garlicki A., 1968. Autochtoniczna seria solna w miocenie Podkarpacia między Skawiną a Tarnowem. Biuletyn Instytutu Geologicznego, 215, 5-77.

Garlicki A., 1979. Sedymentacja soli mioceńskich w Polsce. Prace Geologiczne - Polska Akademia Nauk. Oddział w Krakowie. Komisja Nauk Geologicznych, 119, Zakład Narodowy im. Ossolińskich, Wrocław - Kraków. 
Garlicki A., 1994. Formalne jednostki litostratygraficzne miocenu - formacja z Wieliczki (fm). Przegląd Geologiczny, 42, 1, 26-28.

Garlicki A., 2008. Salt mines at Bochnia and Wieliczka. Przegląd Geologiczny, 56, 8/1, 663-669.

Gaweł A., 1962. Budowa geologiczna złoża solnego Wieliczki. [in:] Czaplicka J. et al. (red.), Czterdzieści lat Instytutu Geologicznego 1919-1959. Cz. 3, Prace - Instytut Geologiczny, 30, Wydawnictwa Geologiczne, Warszawa, 305-331.

Głuszyński A., 2014. Budowa geologiczna strefy brzeżnej Karpat i zapadliska przedkarpackiego w rejonie Tarnowa-Pilzna. Archiwum Wydziału Nauk o Ziemi i Kształtowania Środowiska, University of Wrocław [Ph.D. thesis].

Głuszyński A. \& Aleksandrowski P., 2014 Alongstrike changing structure of the Carpathian thrust front east of Tarnów (SE Poland) as intersection phenomenon related to thrust-floor palaeotopography. Geologia Sudetica, 42, 19-20.

Głuszyński A. \& Aleksandrowski P., 2015. Structural evolution of Carpathian thrust front east of Tarnów (SE Poland). [in:] CETEG 2015: $13^{\text {th }}$ Meeting of the Central European Tectonic Groups \& $20^{\text {th }}$ Meeting of the Czech Tectonic Studies Group (ČTS): Kadañ, 22-25 April 2015, Czech Republic: Abstract Volume, Czech Geological Survey, 20, [on-line:] http://petrol.natur.cuni.cz/ceteg/sites/ default/files/images/pdf/abstract-volume-CETEG2015_ online.pdf.

Głuszyński A. \& Aleksandrowski P., 2016. A deep palaeovalley in the floor of Polish Carpathian Foredeep Basin near Pilzno and its control on Badenian (Middle Miocene) evaporite facies. Geological Quarterly, 60, 2, 493-516. DOI: http://dx.doi.org/10.7306/gq.1297.

Hrdina L.E., 1842. Geschichte der Wieliczkaer Saline. C. Gerold, Wien.

Hudec M.R. \& Jackson M.P.A., 2006. Advance of allochthonous salt sheets in passive margins and orogens. American Association of Petroleum Geologists Bulletin, 90, 1535-1564.

Jodłowski A., 1988. Ogólna charakterystyka stanu badań, źródeł i opracowań. [in:] Jodłowski A. (red.). Dzieje żup krakowskich, Wydawnictwo Muzeum Żup Krakowskich, Wieliczka, 9-15.

Jones P., 1997. The Carpathians of the southern Poland: thrust tectonics or wedge tectonics? [in:] 1997 AAPG International Conference and Exhibition 7-10 September, Vienna, Abstracts, 27-28.

Kolasa K. \& Ślączka A., 1985. Sedimentary salt megabreccias exposed in the Wieliczka mine, Fore-Carpathian Depression. Acta Geologica Polonica, 35, 3-4, 221-230

Kotlarczyk J., 1985. An outline of the stratigraphy of marginal tectonic units of the Carpathian orogen in the RzeszówPrzemyśl area. [in:] Kotlarczyk J. (ed.), Carpatho-Balkan Geological Association XIII Congress: Cracow, Poland, 1985. [4], Geotraverse Kraków - Baranów - Rzeszów Przemyśl - Ustrzyki Dolne - Komańcza - Dukla: guide to excursion 4, Wydawnictwa Geologiczne, Warszawa, 39-64.

Krzywiec P., Aleksandrowski P., Florek R. \& Siupik J., 2004. Budowa frontalnej strefy Karpat zewnętrznych na przykładzie mioceńskiej jednostki Zgłobic w rejonie Brzeska-Wojnicza - nowe dane, nowe modele, nowe pytania. Przegląd Geologiczny, 52, 1051-1059.

Krzywiec P., Bukowski K., Oszczypko N. \& Garlicki A., 2012. Structure and Miocene evolution of the Gdów tectonic "embayment" (Polish Carpathian Foredeep) new model based on reinterpreted seismic data. Geological Quarterly, 56, 4, 907-920. DOI: http://dx.doi. org/10.7306/gq.1067.

Krzywiec P., Oszczypko N., Bukowski K., Oszczypko-Clowes M., Śmigielski M., Stuart F.M., Persano C. \& Sinclair H.D., 2014. Structure and evolution of the Carpathian thrust front between Tarnów and Pilzno (Pogórska Wola area, southern Poland) - results of integrated analysis of seismic and borehole data. Geological Quarterly, 58, 3, 399-416. DOI: $10.7306 / g q .1189$

Krzywiec P., Vergés J., 2007. Role of the foredeep evaporites in wedge tectonics and formation of triangle zones: Comparison of the Carpathian and Pyrenean Thrust Fronts. [in:] Lacombe O., Lavé J., Roure F. \& Vergés J. (eds.), Thrust Belts and Foreland Basins - From Fold Kinematics to Petroleum Systems, New Frontiers in Earth Sciences, Springer-Verlag, Berlin - Heidelberg, 383-394.

Kuc W., 2016. Złoża soli w Polsce w ujęciu przeglądowym. Studia i Materiały do Dziejów Żup Solnych w Polsce, 31, 151-208.

de Leeuw A., Bukowski K., Krijgsman W. \& Kuiper K.F., 2010. Age of the Badenian salinity crisis; impact of Miocene climate variability on the circum-Mediterranean region. Geology, 38, 8, 715-718.

de Leeuw A., Filipescu S., Maţenco L., Krijgsman W., Kuiper K.F. \& Stoica M., 2013. Paleomagnetic and chronostratigraphic constraints on the Middle to Late Miocene evolution of the Transylvanian Basin (Romania): Implications for Central Paratethys stratigraphy and emplacement of the Tisza-Dacia plate. Global and Planetary Change, 103, 82-98. DOI: 10.1016/j.gloplacha.2012.04.008.

Lillie R.J., Johnson G.D.,Yousuf M.H., Zami A.S. \& Yeats R.S., 1987. Structural development within the Himalayan foreland fold-and-thrust belt of Pakistan. [in:] Beaumont C. \& Tankard A.J. (eds.), Sedimentary Basins and Basin Forming Mechanisms, Canadian Society of Petroleum Geologists Memoir, 12, Atlantic Geoscience Society, 379-392.

Machaniec E. \& Zapałowicz-Bilan B., 2005. Micropalaeontological analysis of olistoliths from the Wieliczka Salt Mine (Outer Carpathians, Poland). Studia Geologica Polonica, 124, 273-283.

Morley C.K. \& Guerin G., 1996. Comparison of gravity-driven deformation styles and behavior associated with mobile shales and salt. Tectonics, 15, 1154-1170.

Niedźwiedzki J., 1883. Stosunki geologiczne formacyi solonośnej Wieliczki i Bochni. 1, Spostrzeżenia w naziomie całego obszaru i w kopalni bocheńskiej. Polskie Towarzystwo Przyrodników im. Kopernika, Lwów.

Niedźwiedzki J., 1884. Stosunki geologiczne formacyi solonośnej Wieliczki i Bochni. 2, Utwór solny w Wieliczce. Polskie Towarzystwo Przyrodników im. Kopernika, Lwów.

d’Obyrn K. \& Przybyło J., 2010. Rozpoznanie geologiczne złoża soli kamiennej „Wieliczka” do 1945 roku. Przegląd Górniczy $266,3-4,110-121$. 
Oszczypko N., 1997. The Early-Middle Miocene Carpathian peripheral foreland basin (Western Carpathians, Poland). Przeglad Geologiczny, 45, 10/2, 1054-1063.

Oszczypko N., 1998. The Western Carpathian foredeep development of the foreland basin in front of the accretionary wedge and its burial history (Poland). Geologica Carpathica, 49, 1-18.

Oszczypko N., Krzywiec P., Popadyuk I. \& Peryt T., 2006. Carpathian Foredeep Basin (Poland and Ukraine): Its Sedimentary, Structural, and Geodynamic Evolution. [in:] Golonka J. \& Picha F.J. (eds.), The Carpathians and Their Foreland: Geology and Hydrocarbon Resources, American Association of Petroleum Geologists Memoir, 84, AAPG, 293-350. DOI: 10.1306/985612M843072.

Pettijohn F.J., 1975. Sedimentary Rocks. Harper and Row, New York.

PoborskiJ.\&Skoczylas-CiszewskaK., 1963.Omioceniewstrefie nasunięcia karpackiego w okolicy Wieliczki i Bochni. Annales Societatis Geologorum Poloniae, 33, 3, 339-348.

Połtowicz S., 1977. Uwagi o rozwoju tektonicznym złóż soli kamiennej w Wieliczce i Baryczu. Annales Societatis Geologorum Poloniae, 47, 2, 279-299.

Porębski S. \& Oszczypko N., 1999. Litofacje i geneza piasków bogucickich (górny baden), zapadlisko przedkarpackie. Prace Państwowego Instytutu Geologicznego, 168, 57-82.

Puigdefàbregas C., Muñoz J.A. \& Vergés J., 1992. Thrusting and foreland basin evolution in the Southern Pyrenees. [in:] McClay K.R. (ed.), Thrust Tectonics, Chapman and Hall, London, 247-254.

Rowan M.G., Peel F.J. \& Vendeville B.C., 2004. Gravity-driven fold belts on passive margins. American Association of Petroleum Geologists Memoir, 82, AAPG, 157-182.

Rowan M.G., Peel F.J., Vendeville B.C. \& Gaullier V., 2012. Salt tectonics at passive margins: Geology versus models Discussion. Marine and Petroleum Geology, 37, 184-194.

Sans M. \& Vergés J., 1995, Fold development related to contractional salt tectonics: Southeastern Pyrenean thrust front, Spain. [in:] Jackson M.P.A., Roberts D.G. \& Snelson S. (eds.), Salt Tectonics: A Global Perspective, American Association of Petroleum Geologists Memoir, 65, AAPG, 369-378.

Sieniawska I., Aleksandrowski P., Rauch M.A. \& Koyi H., 2010. Control of synorogenic sedimentation on back and out-of-sequence thrusting: insights from analog modeling of an orogenic front (Outer Carpathians, southern Poland). Tectonics, 29 (TC6012), 1-29. DOI: 10.1029/2009TC002623.

Ślączka A. \& Kolasa K., 1997. Resedimented salt in the Northern Carpathians Foredeep (Wieliczka, Poland). Slovak Geological Magazine, 3, 135-155.

Śliwiński M., Bąbel M., Nejbert K., Olszeska-Nejbert D., Gąsiewicz A., Schreiber B.C., Benowitz J.A. \& Layer P.,
2012. Badenian-Sarmatian chronostratigraphy in the Polish Carpathian Foredeep. Palaeogeography Palaeoclimatology Palaeoecology, 326-328, 12-29.

Talbot C.J. \& Jarvis R.J., 1984. Age, budget and dynamics of an active salt extrusion in Iran. Journal of Structural Geology, 6, 521-533.

Talbot C.J., Medvedev S., Alavi M., Shahrivar H. \& Heidari E., 2000. Salt extrusion rates at Kuh-e-Jahani, Iran: June 1994 to November 1997. [in:] Vendeville B.C., Mart Y. \& Vigneresse J.L. (eds.), Salt, Shale, and Igneous Diapirs in and Around Europe, Geological Society Special Publications, 174, Geological Society, London, 93-11.

Tarka R., 1992. Tektonika wybranych złóż soli w Polsce na podstawie badań mezostrukturalnych. Prace Państwowego Instytutu Geologicznego 137, PIG, Warszawa.

Tołwiński K., 1956, Główne elementy tektoniczne Karpat z uwzględnieniem górotworu Salidów. Acta Geologica Polonica, 4, 2, 75-226.

Urai J.L., Schléder Z., Spiers C.J. \& Kukla P.A., 2008. Flow and transport properties of saltrocks. [in:] Littke R., Bayer U., Gajewski D. \& Nelskamp S. (eds.), Dynamics of Complex Intracontinental Basins: The Central European Basin System, Springer-Verlag, Berlin - Heidelberg, 277-290.

Vergés J., Millán H., Roca E., Muñoz J.A., Marzo M., Cirés J., Den Bezemer T., Zoetmeijer R. \& Cloetingh S., 1995. Eastern Pyrenees and related foreland basins: pre-, synand post-collisional crustal scale cross-section. Marine and Petroleum Geology, 12, 893-915.

Wagner R., Bukowski K. \& Przybyło J., 2008. Petrographic character of coal substance from salt sediments in the Wieliczka mine. Mineral Resources Management, 24, 225-240.

Weimer P. \& Buffler R.T., 1992, Structural geology and evolution of the Mississippi fan foldbelt, deep Gulf of Mexico. American Association of Petroleum Geologists Bulletin, 76, 225-251.

Wiewiórka J., 1988. Warunki geologiczne eksploatacji soli w żupach krakowskich. [in:] Jodłowski A., Wiewiórka J., Piotrowicz J., Keckowa A., Dziwik K. \& Wyrozumski J., Dzieje żup krakowskich, Muzeum Żup Krakowskich, Wieliczka, 37-70.

Wysocka A., Radwański A., Górka M., Bąbel M., Radwańska U. \& Złotnik M., 2016. The Middle Miocene of the Fore-Carpathian Basin (Poland, Ukraine and Moldova). Acta Geologica Polonica, 66, 3, 351-401.

Zejszner L., 1844. Krótki opis geologiczny i górniczy Wieliczki. B. Behr, Berlin.

Żelaźniewicz A., Aleksandrowski P., Buła Z., Karnkowski P.H., Konon A., Ślączka A., Żaba J. \& Żytko K., 2011. Regionalizacja tektoniczna Polski. Komitet Nauk Geologicznych PAN, Wrocław. 